\title{
Aspectos da tradução de versos dos poemas de Púchkin citados em Meu Púchkin, de Marina Tsvetáieva
}

\author{
Paula Costa Vaz de Almeida
}

\begin{abstract}
Resumo: Este artigo propõe uma reflexão sobre alguns aspectos da tradução de versos de poemas de Aleksandr Púchkin citados por Marina Tsvetáieva em seu ensaio Meu Púchkin, escrito em Paris no ano de 1937. Para tanto, recorreu-se à análise e à exposição das estratégias de recriação tanto dos versos citados diretamente quanto daqueles que são citados indiretamente, incorporando-se ao tecido do texto tsvetaieviano. Com isso, busca-se, ainda, pensar o oficio da tradução literária de um modo geral, à luz do que seria a "tarefa do tradutor", segundo Walter Benjamin.
\end{abstract} Palavras-chave: Aleksandr Púchkin, Marina Tsvetáieva, poesia russa, prosa russo-soviética, tradução literária.

Não há um único grande poeta russo contemporâneo, cuja voz depois da Revolução não tenha tremido e não tenha crescido.

(Marina Tsvetáieva)

Esta epígrafe, retirada de Poeta i vrêmia ("O poeta e o tempo"), ensaio de Marina Tsvetáieva (1892-1941) de 1932, é um valioso lembrete para qualquer pessoa que se proponha a aventurar-se no estudo e na tradução da literatura russa do século XX, uma vez que jamais poderá perder de vista que a Revolução Russa, e em especial a Revolução de Outubro, alterou profundamente, tanto em termos estéticos quanto históricos, os rumos daquilo que a partir de então se produziria no âmbito dessa arte. De um lado, em solo nacional, fazia-se uma literatura que se convencionou chamar de literatura soviética (ou literatura russo-soviética quando se busca mais especificidade), em que predominava, pelo menos oficialmente, o realismo socialista; e, de outro, no exterior, a 
chamada literatura russa de emigração, ou emigrée, formada por escritores saídos da Rússia e que constituiriam círculos literários e políticos em Berlim e Praga, depois em Paris. ${ }^{1}$

Meu Púchkin ${ }^{2}$, ensaio cujos problemas e estratégias de tradução este artigo se propõe a comentar, publicado vinte anos após a Revolução de Outubro e cem após a morte de Aleksandr Púchkin (1799-1837), foi escrito por Marina Tsvetáieva quando esta se encontrava emigrada na França. Naquele momento, preparavam-se homenagens oficiais para lembrar a morte do poeta nacional tanto na URSS quanto nos círculos dos emigrados em Paris. E cada lado, naturalmente, tratou de conferir ao evento o caráter ideológico que melhor lhe representava. Tsvetáieva, que mais de uma vez declarara “não estar com ninguém” (TSVETÁIEVA, 1994b, p. 345), escolhe representar um Púchkin íntimo e cotidiano, em tensão com o tempo histórico em que o ensaio se insere, ou seja, o ano de $1937^{3}$. Claro que o ensaio,

1 Vale notar que, com a ascensão dos movimentos nazistas e fascistas na Europa, muitos russos emigrados partem para as Américas, em especial para os Estados Unidos, onde produzem, muitas vezes, em inglês, enquanto tantos outros retornam para a União Soviética. Este é o caso de Marina Tsvetáieva, que chega à Rússia em 1939 e, depois de assistir, neste mesmo ano, às prisões do marido Serguei Efron e da filha Ariadna Efron - ambos acusados de espionagem e atividades antissoviéticas -, em meio à invasão de Moscou pelas tropas alemãs durante a Segunda Guerra Mundial, em 1941, suicida-se em Elabuga, cidade russa da República Tártara.

2 A tradução direta do russo para o português do ensaio Meu Púchkin (em russo, "Мой Пушкин”), acompanhada de notas críticas e explicativas, além de uma introdução, foi o centro do estudo desenvolvido na dissertação que levou o título de "O Meu Púchkin de Marina Tsvetáieva: tradução e apresentação", sob orientação do Prof. Dr. Homero Freitas de Andrade e submetida à Área de Literatura e Cultura Russa da Faculdade de Filosofia, Letras e Ciências Humanas da Universidade de São Paulo, em 2008. A tradução deste texto tão complexo não seria possível sem a paciente e generosa orientação, que proporcionou o aprendizado prático do ofício da tradução, durante os cotejos em que se discutiram os desafios impostos pelo texto e as possíveis estratégias e soluções (algumas delas serão expostas detalhadamente neste artigo), e o estudo teórico do trabalho de tradução por meio da leitura de textos selecionados em conjunto. Além do cotejo com o orientador, inclúa-se nas tarefas a leitura prévia com um falante nativo e qualificado da língua russa, cujo objetivo era confrontar o original e o texto traduzido. O sucesso da missão só foi possível graças à paciência, ao cuidado e à dedicação da, hoje, Profa. Dra. Ekaterina Volkova Américo. Vale dizer, ainda, que, para a elaboração deste artigo, algumas escolhas foram repensadas. Esta não foi, todavia, uma decisão simples. Veio da própria reflexão da natureza do trabalho de tradução aqui proposta, e foi encorajada pela leitura do artigo "Boris Schnaiderman e o autocomentário de tradução", de Walter Carlos Costa (2016), em que o autor aborda, entre outras coisas, a rigorosidade na revisão que o tradutor empreendia a cada reedição e a autorrevisão em voz alta, a fim de controlar eventuais omissões.

3 É importante notar que o ano de 1937 é crucial para Tsvetáieva ainda em mais um sentido: sua filha Ariadna Efron decide voltar à Rússia em março e, em setembro, será a vez de seu marido Serguei Efron retornar. O ex-cadete do Exército Branco convertido em agente stalinista envolve-se no assassinato de Ignace Reiss, espião soviético que rompera com o partido por discordar das perseguições promovidas por Stálin, declarando seu apoio a Leon Trótski e à Quarta Internacional, e é levado clandestinamente para a União Soviética. 
inclusive pela força poética por meio da qual são representadas as reminiscências da infância, revela um Púchkin universal. Entretanto, é preciso destacar que o que sobressai é o Púchkin localizado, figura corriqueira na vida russa.

Nesse contexto, o Púchkin de Meu Púchkin, ou seja, o Púchkin segundo Marina Tsvetáieva, é um Púchkin que pode ser, ao mesmo tempo, mestre, negro, monumento, perseguido, assassinado e amaldiçoado, sendo, sobretudo, poeta e o primeiro professor, aquele que lhe ensinará as lições mais fundamentais. Púchkin é a personagem principal de uma narrativa construída a partir do olhar da criança, ou seja, da menina diante do porvir em confronto com o escrutínio da mulher adulta, a qual, para tanto, repassa "passo a passo o Púchkin" (TSVETÁIEVA, 2008, p. 70) de sua infância. Nesse percurso, ela retoma seus poemas favoritos e transmite ao leitor as lições mais valiosas que aprendera, ainda criança, com o poeta nacional. Com isso, Tsvetáieva recupera em seu ensaio estrofes e versos que considera mais significativos. No entanto, ela não se limita a simplesmente citar e analisar os versos e estrofes que seleciona. Além das diversas sugestões e referências indiretas, a prosa tsvetaieviana parece contaminar-se com a poesia puchkiniana, inundar-se dela. A impressão que se tem é de um movimento natural, como se a força do verso de Púchkin se incorporasse às frases de Tsvetáieva, em alguns momentos, sobrepujando-as. Trata-se de um texto que exige um olhar atento do tradutor, pois, em realidade, há ali um intenso trabalho de construção, desconstrução e ressignificação das poesias escolhidas. Que caminhos seguir? Que estratégias adotar? Que tarefas impor-se?

Walter Benjamin, em seu conhecido ensaio "A tarefa do tradutor", afirma que uma tradução que pretende servir como simples meio de comunicação não pode "fazer passar mais do que a informação", quer dizer, aquilo que é "inessencial" (BENJAMIN, 2008, p. 82). E o essencial aqui, antes de mais nada, não é a fidelidade estrita ao sentido, mas, como afirma o mesmo Benjamin acerca da tradução em geral, está na "forma como o que se quer dizer se articula com o modo do querer dizer nessa palavra” (BENJAMIN, 2008, p. 93).

Ora, seja no nível da escolha vocabular, seja no que se refere ao arranjo das frases, a elaboração que se opera na prosa tsvetaieviana em muito se assemelha ao trabalho de construção do texto poético. Tal efeito é logrado a partir do jogo que Tsvetáieva estabelece entre a percepção da criança e uma possível intencionalidade do poeta. O jogo consiste em colocar a criança na posição de aprendiz, que deve, antes de ser iniciado no ofício, decifrar enigmas, adivinhas, trava-línguas, homonímias, polissemias, as quais, sob o pretexto da brincadeira, lança ao leitor um desafio em cada linha. E, por consequência, ao tradutor, a cada novo verso citado, do qual a poeta se apropria. 
Ao traduzir o ensaio Meu Púchkin, portanto, do ponto de vista da intencionalidade, teve que se levar em conta que, nesse caso, não se trata de uma, mas de duas intencionalidades: a de Tsvetáieva e a de Púchkin. Desse modo, e partindo da concepção benjaminiana de que a tarefa do tradutor "consiste em encontrar a intencionalidade orientada para a língua da tradução, a partir da qual nesta é despertado o eco do original" e que esse é um trabalho "no qual as próprias línguas coincidem umas com as outras, completadas e reconciliadas no modo do seu querer dizer" (BENJAMIN, 2008, p. 92), é possível afirmar que, no presente caso, temos no original, num primeiro momento, não apenas uma língua, a russa, mas duas línguas, que são poéticas: a de Púchkin, que produziu sua obra no século XIX em solo russo, e a de Tsvetáieva, que escreve na Paris sombria dos anos de 1930. E aqui é válida outra reflexão empreendida por Benjamin. Ao criticar a teoria que pretende que a tradução seja uma imitação do original, ele argumenta que o original transforma-se ao longo de sua sobrevida. Isso quer dizer que as palavras e as tendências poéticas de uma dada época podem desaparecer, renovar-se, tornar-se arcaicas. Assim, o que se coloca logo de saída é que tal problema é intrínseco ao original sobre cuja tradução tratamos aqui. O desafio imposto, portanto, está em primeiro, por meio da análise, distinguir "o que se quer dizer" de "como se quer dizer" de Púchkin e Tsvetáieva, para, uma vez tendo conciliado essas duas instâncias, proceder, agora por meio da tradução, à tarefa de fazer as distintas línguas, notadamente o português e o russo, completarem-se nas intencionalidades que estão em jogo. Parafraseando Benjamin, depois de refletir "sobre o processo de maturação da palavra estrangeira", que se dá no interior de Meu Púchkin e cobre em tempo mais de um século - da época de Púchkin à época de Tsvetáieva -, foi necessário dar atenção "às dores de parto da palavra própria” (BENJAMIN, 2008, p. 87), sem nunca trair a intencionalidade do poeta em nome da intencionalidade da poeta.

Sendo assim, vejamos com exemplos como isso se deu na prática.

Um recurso amplamente usado pela autora é a incorporação de versos de Púchkin ao discurso da criança, a começar por aquele que viria a ser seu "primeiro Púchkin": "Tsigâni’” ("Os ciganos").

- Então, era uma vez um jovem. Não, era uma vez um velho, e ele tinha uma filha. Não, é melhor eu contar em versos. Ciganos em ruidoso tropel - Vão pela Bessarábia viajando - Hoje à beira do rio estão ao léu - Em 
suas tendas rotas pernoitando - Que liberdade alegre sua pousada - e assim por diante - sem parar e sem vírgulas de permeio. - até: o retinir da bigorna ambulante, que, eu acho, deve ser um instrumento musical, e deve ser isso mesmo - acho eu. (TSVETÁIEVA, 2008, p. 51).

A criança recita aqui os cinco primeiros versos da estrofe de abertura do poema:

Ciganos em ruidoso tropel

Vão pela Bessarábia viajando

Hoje, à beira do rio estão ao léu,

Em suas tendas rotas pernoitando

Que liberdade alegre sua pousada
Цыганы шумною толпой

По Бессарабии кочугот.

Они сегодня над рекой

В шатрах изодранных ночуют.

Как вольность, весел их ночлег

(PÚCHKIN, 2006, p. 288)

Este tipo de apropriação, que visa à incorporação dos versos de Púchkin à fala da criança, é um procedimento que perpassa todo o ensaio. Além disso, os poemas de Púchkin são também citados na forma do discurso direto e utilizados, entre outras coisas, ora para explorar a polissemia de certas palavras com base nas confusões ensejadas pelo pensamento infantil da criança em processo de alfabetização, ora para potencializar, pelas lentes da poeta adulta, o contato com o elemento poético proporcionado pela leitura da obra de Púchkin, ora como simples pretexto para compartilhar com o leitor os ensinamentos do mestre.

Como estratégia de tradução dos versos e/ou estrofes dos poemas de Púchkin citados por Tsvetáieva em Meи Púchkin, procurou-se preservar, na medida do possível, as rimas e a métrica dos originais. Desse modo, os versos iâmbicos e trocaicos dos tetrâmetros puchkinianos, na versão para o português, foram recriados em versos octossílabos, decassílabos ou dodecassílabos.

Tomando como exemplo as citações acima, pode-se notarque, além de o texto de Púchkin serincorporado à fala da criança, tanto a própria fala da criança quanto a reflexão da autora são contaminadas pelo ritmo do verso puchkiniano. Uma vez que se optou, ao traduzir os versos de "Tsigâni" ("Os ciganos") citados por Tsvetáieva, por adotar como métrica em português o verso decassilabo, também as passagens que reproduzem, no original, os pés do verso em russo, foram recriadas com as respectivas medidas. Dessa maneira, as duas frases que se seguem à citação direta do poema - ou seja: "e assim por diante - sem parar e sem vírgulas de permeio" - têm, respectivamente, cinco e dez sílabas tônicas. 
Ainda ao contar sua experiência com o poema sobre os ciganos, a autora lança mão de um expediente que se repetirá em todo o texto. Partindo da fala da criança, que, a essa altura, já conquistara, não sem alguma resistência, uma audiência composta pela ama da irmã mais nova e por sua amiga, uma costureira que viera visitar-lhes, a poeta procede à citação direta de dois versos do poema. Em seguida, numa espécie de discurso indireto livre, mistura a voz da narradora, a mulher adulta que vive no estrangeiro, à da personagem, a criança que "aos cinco anos, já era recurso espiritual de alguém” (TSVETÁIEVA, 2008, p. 50), e reverbera em outras instâncias da narrativa, como, por exemplo, na fala das personagens ao final da seguinte passagem:

- Então, essa filha se chamava Zemfira (em voz alta e ameaçadora:)

Zemfira - a filha diz ao velho que Alieko vai morar com eles, porque ela o encontrou no deserto:

Encontrei-o no deserto vagando

E convidei-o ao pouso cigano.

E o velho ficou contente e disse para irmos numa mesma telega:

"Numa telega seguimos o curso - tá-tá-tá-tá-tá, tá-tá-tá-tá-tá - E as aldeias percorra com o urso.."

- O urso - ecoou a bá. (TSVETÁIEVA, 2008, p. 52).

Além da poesia de Púchkin invadindo pela força da repetição de palavras-chaves as instâncias narrativas da prosa, influindo no modo como elas se relacionam para criar a representação pretendida pela narradora, cabe destacar no trecho acima alguns detalhes linguísticos, os quais se buscou recuperar na tradução e que concorrem para o apagamento das marcas entre prosa e poesia. O primeiro é a passagem do discurso da criança da terceira pessoa do plural, "eles", para a primeira pessoa do plural, "nós", incluindo-se, assim, na narrativa do poema. Dessa maneira, a pequena Marina deixa de ser apenas uma personagem criada pela narradora no âmbito da prosa, para se tornar personagem de "Tsigâni”" ("Os ciganos"). A segunda relaciona-se com a substituição de dois versos do poema pela sequência “tá-tá-tá-tá-tá, tá-tá-tá-tá-tá". Os versos omitidos aparecem destacados em itálico na comparação da tradução com o original a seguir:

Numa telega seguimos o curso; Servimos bem para qualquer oficio:
В одной телеге мы поедем;

Примись за промысел любой: 
Forje o aço ou faça uma canção pr'ouvido

$\mathrm{E}$ as aldeias percorra com o urso.
Железо куй - иль песни пой

И селы обходи с медведем.

(PÚCHKIN, 2006, p. 289)

Ao omitir os dois versos, a criança acaba por marcar o ritmo do poema "Tsigâni"” ("Os ciganos"). Por essa razão, se, no texto tsvetaieviano original, temos quatro sílabas em cada segmento (em russo não transliterado: "ma-ma-ma-ma, ma-ma-ma-ma"), na tradução para o português, uma vez que se optou por versos decassílabos, é preciso acrescentar uma sílaba a mais a cada parte do segmento (“tá-tá-tá-tá-tá, tá-tá-tá-tá-tá").

As palavras descobertas nas "leituras roubadas" não tardam a fazer parte do vocabulário da criança. No entanto, a pouca experiência da menina curiosa, dona de uma timidez atrevida, logo começa a provocar confusões e mal-entendidos. Num primeiro momento, o uso de um vocabulário precoce para sua idade resulta em pequenos conflitos familiares, especialmente com a mãe.

Sob influência contínua da leitura roubada, naturalmente, o vocabulário enriquecia-se.

- De qual boneca você gosta mais: a da tia de Nuremberg ou a da madrinha de Paris?

- A de Paris.

- Por quê?

- Porque ela tem olhos apaixonados.

Mamãe, ameaçando:

- Como?!

- Eu, - me dando conta - Eu quis dizer: assustados.

A mãe ameaçando mais ainda:

- E mais essa! (TSVETÁIEVA, 2008, p. 56).

A interpretação que a narradora faz do episódio é bastante exemplar do método empregado pela autora em "Meu Púchkin":

Minha mãe não entendeu nada. Minha mãe entendeu o sentido e, quem sabe, indignou-se com razão. Mas entendeu - errado. Os olhos não eram apaixonados, mas fui eu que atribuí aos olhos o sentimento de paixão despertado em mim por este - olhar (e pelo véu rosado, e pela naftalina, e pela palavra Paris, e pelo caso do baú, e pela inacessibilidade da boneca). Não sou a única. Todos os poetas. 
(E depois duelam entre si - porque a boneca não é apaixonada!) Todos os poetas, e Púchkin o primeiro. (TSVETÁIEVA, 2008, p. 57).

O que está em jogo aqui não é, necessariamente, o significado mais imediato das palavras, mas aquele sentido específico que a criança, endossada pela poeta, atribui às coisas do mundo que a cerca, seja ao olhar apaixonado da boneca parisiense, seja à estátua de Púchkin, ao quadro de Naúmov, ao armário secreto ou às palavras encontradas nos poemas de seu primeiro poeta. $\mathrm{E}$ mais que isso, será a partir das contraposições criadas entre suas interpretações infantis e os conflitos que essas suscitavam com a mãe, que a narradora será capaz de repassar seu itinerário poético e refletir sobre sua formação, como mulher e como poeta. Um exemplo disso é o viés um tanto quanto determinista por meio do qual a cena da conversa entre Tatiana e Oniéguin, personagens do romance em versos Evguéni Oniéguin, no jardim, à qual a criança assiste em uma apresentação pública, é interpretada pela mulher adulta.

Este banco, no qual eles não se sentaram, revelou-se determinante. Nem naquela época nem mais tarde, eu jamais gostei de quando se beijavam, sempre - de quando se separavam. Jamais - de quando se sentavam, sempre - de quando se apartavam. Minha primeira cena de amor foi de não-amor: ele não amava (isso eu entendia), por isso não tinha se sentado, ela amava, por isso tinha se levantado, eles não passaram juntos um instante sequer, não fizeram nada juntos, fizeram exatamente o contrário um do outro: ele falava, ela calava, ele não amava, ela amava, ele partiu, ela ficou, de modo que, se erguerem a cortina - ela continua lá, sozinha, e, talvez, sente-se de novo, porque ela estava em pé apenas porque ele também estava, mas daí ela desabou, e assim ficará sentada para todo o sempre. Tatiana está sentada naquele banco para todo o sempre.

Essa minha primeira cena de amor determinou todas as outras, toda essa paixão pelo amor infeliz, impossível, não correspondido. Desde aquele instante eu não quis mais ser feliz e me condenei ao - não-amor. (TSVETÁIEVA, 2008, p. 59).

Assim, se o monumento a Púchkin representou a primeira lição de números, de proporções, de matérias, de hierarquia e de ideia, além da confirmação prática posteriormente verificada de que "de mil bonequinhas ainda que empilhadas uma sobre a outra, não se faz um Púchkin" (TSVETÁIEVA, 2008, p. 40), a Tatiana de Púchkin representou: "Lição de coragem. Lição de orgulho. Lição de fidelidade. Lição de destino. Lição de solidão” (TSVETÁIEVA, 2008, p. 60). 
A harmonia dos sentidos que a criança constrói ao criar seu mundo é, como se vê, sempre quebrada quando há a participação da mãe. Nos casos acima, a incompreensão surge a partir das imagens de Púchkin e suas personagens. Mas a principal é aquela surgida a partir das perguntas da mãe sobre os versos trazidos pelo material didático de seu meio-irmão mais velho, chamado de "a antologia do Andriucha". Maria Mein aproveita-se de poemas históricos, como "Полтава" ("Poltava"5), para ensinar aos filhos e enteados a história da Rússia.

Para o tradutor, o desafio colocado é recriar nos diálogos os jogos de palavras suscitados pelas confusões geradas pela falta de repertório sobre a história de seu país, natural de criança em tão tenra idade, a coloquialidade típica da conversa de uma mãe com seus filhos, independentemente do grau de exigência das perguntas, e os versos de Púchkin, que se incorporam à conversa sem afetação.

"Quem é ele?" E de novo a mamãe ao Andriucha: “Então, Andriucha, quem é ele?" E de novo o Andriucha com dignidade, tristeza e até mesmo revolta: "E eu é que vou saber?" (Estranho mundo este - o da poesia, em que os adultos perguntam e as crianças respondem!) "E você, Mússia? Sabe quem é ele?" - "Um Gigante". - "Por que um Gigante?" - "Porque ele consertou de vez". - "Mas o que significa 'E de Pedro para a felicidade??" - "Não sei". - "Diga, o que significa de Pedro?" (Nada na cabeça, a não ser a grafia "depedro"() "Você não sabe o significado de: de Pedro?" - "Não". - "E o que é do Andriucha, você sabe?" - "Sei, o cavalinho de balanço7 do Andriucha, a bicicleta do Andriucha, o trenó do Andriucha..." - "Tá bom, tá bom. Então, de Pedro é a mesma coisa. De Pedro. Você entende, agora, o que significa de Pedro? E o que é felicidade - você sabe? (Silêncio.) Você não sabe o que é felicidade?" - "Eu sei. Felicidade é quando nós estamos voltando do passeio e de repente o vovô chega, e também quando eu achei na minha cama..." - "Chega. Para de Pedro a felicidade significa para a felicidade de Pedro. E que Pedro é esse?” - "Eh..." "Quem é ele? Então?” - "Mas é o hóspede maravilhoso. Olha demoradamente para aquela direção. Onde o hóspede maravilhoso acabou de sumir..." - "E como se chama este

5 Poema longo que Púchkin escreveu de 3 a 13 de outubro de 1828. O tema da obra é a Batalha de Poltava, uma das mais famosas batalhas da Grande Guerra do Norte (17001721), e a narrativa gira em torno de Vassíli Leontievitch Kotchubéi (1640-1780) e de seu principal oponente, Ivan Stiepanovitch Mazepa (1639-1709), hetman da Ucrânia de 1687 a outubro de 1709.

6 Em russo, "Петрово", adjetivo derivado do nome próprio "Пётр".

7 No original, palavra alemã transliterada para o russo que significa "cavalo de balanço". 
hóspede maravilhoso?”. Eu, timidamente: “Seria Pedro?” (TSVETÁIEVA, 2008, p. 68).

Questões relativas à efetividade do método à parte, o fato é que, ao provocar os filhos com perguntas sobre personalidades históricas da Rússia, sendo Pedro, o Grande a mais fundamental, a mãe está, na realidade, valendo-se de um método utilizado pelo próprio Púchkin. Como observa Tsvetáieva nos parágrafos finais da passagem:

Só agora, repassando passo a passo o Púchkin da minha infância, vejo o quanto Púchkin gostava de recorrer a perguntas (...).

Mas não posso, da minha pessoa de então e de agora, não dizer que a pergunta nos versos é um recurso irritante, pelo menos porque cada por que exige e promete um porque e isso enfraquece o próprio valor de todo o processo, toda a poesia se converte em um período, concentrando nossa atenção para o objetivo final exterior, que o poema não deve fazer. A pergunta insistente converte o poema em enigma e tarefa, e se todo o poema é em si mesmo um enigma e uma tarefa, a resposta a este enigma não é dada, e para o que aquela tarefa propõe não há solução no gabarito. (TSVETÁIEVA, 2008, p. 70).

Ainda na antologia do Andriucha, porém já livre das perguntas da mãe, a pequena Marina conhece os primeiros poemas de terror: Utoplennik ${ }^{8}$ ("O afogado"), Vurdalak" ("Vurdalak") e Besi ${ }^{10}$ ("Os diabos"). Surpreendentemente, os mal-entendidos ocasionados pelos jogos de perguntas e respostas de sua mãe e de seu mestre começam a se dissipar na leitura dos poemas. Sem a exigência das perguntas, a criança era livre para interpretar, de modo que as confusões e os jogos de palavras explorados pela poeta operam em um nível ainda mais complexo.

Em primeiro lugar, aquelas crianças, ou seja, nós que brincamos sozinhos no rio, em segundo, nós que vulgarmente chamamos o nosso pai: papá! e em terceiro, nós que não temos medo de morto. Porque elas não gritam amedrontadas, mas alegres e até cantarolando, assim: "Papá! Papá! Veja nossas redinhas! Elas trouxeram até nós! Um morto!" - "É mentira de

8 Poema de Púchkin de 1928.

9 Poema de Púchkin que faz parte do ciclo "Canções dos eslavos do norte" ("Pesni zapadnikh slavian"), de 1834.

10 Poema de Púchkin escrito em 1830. 
vocês, capetinhas, uma mentira - rabujou o pai. - Ah, e ainda dizer qu'eu os fiz! Ora essa, vejam qu’obra: um morto!' (TSVETÁIEVA, 2008, p. 71).

Do ponto de vista da língua literária, o que se tem aqui é uma exploração de certo modo prosaica, porém absolutamente expressiva, das capacidades sonoras e visuais da língua russa. O reconhecimento com o mundo narrado por Púchkin no poema é imediato. Em um processo bastante similar ao que acontece em Tsigâni ("Os ciganos"), muito rapidamente a voz narrativa passa da terceira pessoa do plural ("aquelas crianças") para a primeira do plural ("nós"). Não se trata apenas de identificação ou de alguma outra forma de reconhecimento mais imediato com as crianças ali retratadas. Há, antes, um processo de transmutação que a permite - agora sim imediatamente - fazer todas as conexões necessárias para recriar a atmosfera de horror suscitada pelo poema de Púchkin.

Retomando a citação acima, pensemos no que está dito por Púchkin, por um lado, e o que é compreendido pela criança, por outro.

"Papá! Papá! Nossas redinhas

Trouxeram até nós! Um morto!"

- "Mentira de vocês, capetinhas, mentira - rabujou o pai.

- Ah, e ainda dizer qu'eu os fiz!

Ora essa, vejam qu'obra: um morto!"
«Тятя! тятя! наши сети

Притащили мертвеца».

«Врите, врите, бесенята,»-

Заворчал на них отец; -

«Ох, уж эти мне робята!

Будет вам ужо мертвец!»

(PÚCHKIN, 2006, p. 118)

Em russo, o jogo é feito entre a interjeição " “ж/ жжo" e o substantivo "yжu", que significa "cobra". Na falta de uma interjeição em português que permitisse recriar imediatamente tal jogo, a solução proposta foi promover a contração da expressão “que obra!", valendo-se, para tanto, de uma expressão que, em português do Brasil, também faz as vezes de interjeição, além de um expediente bastante comum na poesia em língua portuguesa, a saber, o uso do apóstrofo para promover uma elipse de fonema por meio da aglutinação da conjunção à palavra seguinte. Com isso, logrou-se aproximar, por meio da sonoridade, como, ademais, acontece no russo, a expressão "qu〉obra!" da palavra "cobra".

O jogo aqui empregado é fundamental para as associações que se operam a seguir. A narrativa criada pela poeta em torno do poema Utoplennik ("Os afogados") prepara o leitor para o que está por vir. Ocorre que, a partir daqui, do ponto de vista da contaminação da prosa tsvetaieviana pela poesia de Púchkin, aquilo que se desenhava em segundo plano, começa a emergir como força fundamental. A 
contaminação dos versos puchkinianos deixa de ser unicamente pela via vocabular e passa, gradualmente, a se desenvolver de modo mais pleno no plano imagético. É esse procedimento que permite associar a morte por afogamento do balseiro à morte por câncer do avô:

(...) o vovô nem sequer morreu afogado, mas morreu de câncer - de câncer? Só que:

E foi então que no corpo inchado

Os cânceres negros aferroaram!

...resumindo, através da porta de vidro da sala de jantar - nas colunas fantasmagóricas do balcão e embaixo delas, trazendo todo o rio atrás de si:

Desde manhã o mau-tempo braveja

Vem a noite e a tempestade gela,

Chega então o afogado que golpeia

No portão e também na janela.

O morto-qu'obra com o duplo rosto do vovô Aleksandr Danílovitch e do balseiro que afundou. (TSVETÁIEVA, 2008, p. 72).

Do amor às paixões, do ponto de vista linguístico, os poemas de horror representam um avanço na capacidade da menina de interpretação da poesia de Púchkin. Ela ultrapassa aquele primeiro reconhecimento sonoro imediato da palavra e a incompreensão causada pelas perguntas da mãe para começar a construir imagens bastante sofisticadas. É importante observar que as descrições presentes nas reminiscências líricas e ficcionalizadas de Marina Tsvetáieva são extremamente plásticas. As pequenas tramas da infância, ambientadas em uma Rússia que já não existe mais, qual eco de uma pátria impossível, cristalizam os movimentos da narrativa por meio não apenas da transfiguração da experiência, mas da própria poesia de Púchkin. Assim, na parte final do período dedicado a Besi ("Os diabos"), ela declara:

Leitor! Eu sei que "Vocês, olhos, olhos azuis" - não é de Púchkin, mas de uma canção, talvez até de uma romança, mas, naquela época, eu não sabia disso e, agora, dentro de mim, onde há tudo - ainda é tudo, também não sei, porque "rasgando o meu coração" e "a saudade do coração", pequena diabinha e bem-amada, estrada e estrada, separação e separação, amor e 
amor é uma coisa só. Tudo isso se chama Rússia e minha infância, e se vocês abrirem a minha barriga, além de diabos passando com nuvens e nuvens passando com diabos, vocês também descobrirão em mim aqueles dois olhos azuis. É a minha essência. (TSVETÁIEVA, 2008, p. 76-77).

Na leitura desse poema, "o mais aterrorizante por afinidade e o mais afim por aterramento” (TSVETÁIEVA, 2008, p. 74) tudo foi compreensão. A descrição é pictórica e construída por meio de um encadeamento de metonímias. Versos e palavras fundamentais do poema são retomados, pois representam a Rússia, o poema como um todo e a narradora, que na passagem se comporta como uma espécie de eu-lírico. E não só cada elemento separadamente, mas o quadro completo que se pinta a partir da união de todos eles, reunidos dessa forma no interior da poeta, constitui uma metonímia na medida em que são aquela essência que forma a pessoa.

Meu Púchkin pode ser considerado o mais bem acabado entre os trabalhos em prosa de Marina Tsvetáieva. Isso porque nele se reúnem os três componentes fundadores de seu pensamento artístico de modo condensado e harmônico: o amor, o poeta e a poesia. Aqui interessa-nos, especificamente, o que pode ser considerado o terceiro plano temático do ensaio, o encontro com a essência da poesia, que se dá por meio do poema "Ao mar", último poema abordado e que ocupa toda a parte final do ensaio.

Depois de afundar-se no armário secreto para ler As obras completas de $A$. S. Púchkin, do Púchkin lírico e heroico, depois de todas as antologias e cartilhas escolares e depois do Púchkin enigmático e incompreensível da mãe, a criança, finalmente, ouve pela primeira vez o chamado inconteste da poesia, que a atingiu no verão de 1902, em Gênova, por meio do poema de Púchkin "Ao mar" ("K moriu"). A pequena poeta tinha 10 anos de idade quando a família foi para "o mar" a fim de tratar a tuberculose da mãe. A brincadeira daqueles dias resumia-se a copiar repetidamente, e recomeçar a cada erro, o poema de Púchkin em um caderno por ela mesma forjado, até o dia em que conhece o mar verdadeiro - "azul e salgado" - e a menina ouve, pela primeira vez, o apelo dos elementos livres da natureza:

E, de repente, dando-lhe as costas, escrevo com uma lasca de rocha no rochedo.

Adeus, elemento livre!

Os versos são longos, e eu comecei do alto, o quanto a mão alcançava, mas os versos, por experiência própria eu sei, são tão longos que nenhum 
rochedo basta, e ali perto não há outro que seja tão liso, mas apesar disso, as letras aperto e aperto, espremo e espremo, e as últimas não passam de conchinhas, e sei que agora virá a onda e não deixará que eu termine, então o desejo não se realizará — qual desejo? ah, Ao Mar! — mas, quer dizer que já não há nenhum desejo? Mas, mesmo assim, até sem desejo! eu preciso acabar de escrever antes da onda, acabar tudo antes da onda, mas a onda já vem vindo, e eu bem que ainda tenho tempo de assinar:

\section{Aleksandr Serguéievitch Púchkin -}

E daí tudo é lavado, como que lambido por uma língua, e de novo estou toda molhada, e de novo a ardósia lisa, já preta agora, como aquele granito... (TSVETÁIEVA, 2008, p. 95).

Ao escrever essas palavras, a criança estava apenas obedecendo aos comandos dos elementos livres do mar verdadeiro e do mar de Púchkin. Ao final, ao assinar o nome do Sol da poesia russa, funde-se com um todo maior, que compreende todos os poetas. E o banho involuntário no mar é o seu batismo. Se para Púchkin, o mar representava a força primordial da natureza, para Tsvetáieva essa força é representada pela poesia: "Os elementos livres são, decerto - os versos, e em nenhuma outra poesia isso é dito com tanta clareza." (TSVETÁIEVA, 2008, p. 85).

E essa descoberta é feita por meio do poema Ao mar, ou seja, Púchkin a conduziu desde o primeiro despertar até o momento em que se completa o processo de formação da poeta. O jogo de palavras engendrado por Púchkin e assimilado por Tsvetáieva constitui-se em uma formidável assonância na língua original. Em russo, stikhia (“стихия") são os quatro elementos da natureza, ou seja, o fogo, a água, a terra e o ar, que no âmbito dos jogos formulados em Meu Púchkin representam a força cósmica e caótica que se revela por meio da natureza e dos sentimentos humanos ao poeta, o qual, por sua vez, deve desmitificá-la por meio de fórmulas poéticas capazes de organizar o caos. Já a palavra russa stikhi (“стихи") significa "versos". A partir disso, é possível pensar que será por meio da poesia que os elementos se revelarão a Tsvetáieva.

E digo mais: a ignorância dos meus tempos de criança que confundia elemento livre com versos era uma - intuição: o "elemento livre" eram os versos, mas não o mar, os versos, ou seja, o único elemento ao qual jamais se diz adeus. (TSVETÁIEVA, 2008, p. 98) 
Onde se lê "elementos livres", a criança, pequena poeta, lia "versos livres", jogo possível apenas em russo. Para a tradução, portanto, recorreu-se às controversas notas de rodapé, as quais se deve evitar até o momento em que se tornam imprescindíveis.

Estamos, possivelmente, diante de um dos vocábulos de mais difícil tradução da língua russa, e eles não são poucos. Isso não apenas devido ao seu significado, mas, especialmente, pela semelhança que as palavras guardam entre si e as consequentes possibilidades de criação poética ensejadas por essa similitude. Além do encontro com a palavra no poema de Púchkin (que, na realidade, não faz esse jogo, quem o percebe é a criança, ou pelo menos é disso que, na busca de atestar sua vocação, a poeta tenta convencer o leitor), Tsvetáieva cita da seguinte maneira o poema de Boris Pasternak, seu irmão de poesia, "Tema e variações. Variante 1. A original" ("Тема и варианциями. Варианция I. Оригинальная.”), de 1918, inspirado em “Ао mar”, de Púchkin.

Ao mar era: o mar + o amor que Púchkin lhe tinha, o mar + o poeta, não! o poeta + o mar, dois elementos, sobre os quais Boris Pasternak de modo inesquecível escreveu:

O elemento do elemento livre

Com o elemento livre do verso,

omitindo ou deixando subentendido o terceiro e único: o elemento lírico. (TSVETÁIEVA, 2008, p. 97).

Entramos, nesse momento, no campo espinhoso da "intraduzibilidade". E o que se coloca aqui não é exatamente a correspondência ou a falta de correspondência entre o significado das palavras nas línguas literárias de chegada e de saída. Também não está colocado o sentido de cada palavra isoladamente, em suas respectivas línguas, em estado de dicionário. E ainda que a própria tradução para o português como "elemento" seja incompleta, não está em jogo sequer o sentido, ou seja, a informação transmitida pela obra no original. Coloca-se aqui algo tanto mais complexo quanto mais profundo, a saber: a "tradutibilidade do original". Segundo Benjamin:

Até que ponto uma tradução é capaz de corresponder à essência desta forma, isso é determinado objetivamente pela tradutibilidade do original. Quanto menos valor e dignidade a sua língua tiver, quanto mais ela for informação, menos há a ganhar na tradução, até que o total predomínio 
desse sentido, muito longe de servir de alavanca para uma tradução formalmente perfeita, acabará por fazê-la malograr. Quanto mais elevada for a forma de uma obra, tanto mais ela será traduzível, ainda que a tradução aflore apenas ao de leve o seu sentido. [...] Mas existe um ponto de paragem e atenção (ein Halten), que, no entanto, só o texto sagrado pode garantir: nele, o sentido deixou de ser a linha de separação entre a torrente da língua e a torrente da revelação. Se o texto pertencer, de forma não mediatizada, sem a mediação do sentido e pela sua literalidade, à língua verdadeira, à verdade ou à doutrina, existirá nele uma tradutibilidade de princípio. Agora já não em função de si mesmo, mas apenas das línguas. $\mathrm{Na}$ relação com ele exige-se à tradução uma confiança tão ilimitada que, no plano desta literalidade e liberdade, sob a forma da versão interlinear, a língua e a revelação terão necessariamente de se conjugar sem tensões, como no texto original. Na verdade, todos os grandes textos, e em mais alto grau os sagrados, contêm nas entrelinhas a sua tradução virtual. (BENJAMIN, 2008, p. 97-98).

Buscar uma tradução que integre as línguas de chegada e de saída em uma "língua verdadeira" capaz de revelar "a tradução virtual" contida "em todos os grandes textos" é a mais difícil, ambiciosa e, talvez, incontornável tarefa que o tradutor literário de um modo geral, e o de poesia em particular, pode se impor, ainda que este tenha a consciência de que essa batalha dificilmente será plenamente vencida. Contudo, não existe pecado em buscar o ideal, em aceitar a utopia, por mais romântica que essa visão possa parecer. Mesmo porque uma tradução jamais será uma obra definitiva. Diferentemente do original, que subsiste no decorrer de séculos graças à potência de sua universalidade, a tradução está sujeita à ação do tempo. E da mesma forma que corre o risco de desaparecer, a palavra pode sobreviver em sua língua e outras possibilidades de traduzi-la podem surgir. Assim, a obra se revela a leitor que não teria outro modo de conhecê-la se não por meio da tradução. Como bem sintetizou Marina Tsvetáieva em Poeta i vrêmia ("O poeta e o tempo"):

Uma obra universal é aquela que na tradução para outra língua e para outra era - na tradução para a língua de outra era - o mínimo - nada se perde. Tendo dado tudo à sua própria era e terra, tudo será dado mais uma vez em todas as terras e eras. Ao revelar sua própria era e terra até seus limites - revela-se de modo ilimitado tudo o que não é nem a terra nem a era: por eras eternas. (TSVETÁIEVA, 2008, p. 97-98). 


\section{Referências}

BENJAMIN, W. A tarefa do tradutor (tradução de João Barrento). In: BRANCO, C. L. (org.). A tarefa do tradutor, de Walter Benjamin: quarto traduções para o português. Belo Horizonte: Fale/UFMG, 2008.

COSTA, W. C. Boris Schnaiderman e o autocomentário de tradução. TradTerm, v. 28, 2016, pp. 23-34.

PÚCHKIN, A. S. Stikhotvorenia i poemi. Moscou: Eksmo, 2006.

TSVETÁIEVA, M. Meu Púchkin. In: ALMEIDA, Paula. O “Meu Púchkin” de Marina Tsvetáieva: tradução e apresentação. Dissertação - Universidade de São Paulo. São Paulo, 2008. 155p.

. Moi Puchkin. In: Sobranie sotchineni: V 7 t. T. 5: Avtobiografitcheskaia proza. Stati.

Esse. Perevodi. Sost., podgot. teksta i komment. A.A. Saakiants i L. A. Mnukhina. Moscou: Ellis Lak, 1994a.

Poeta i vrêmia. In: Sobranie sotchineni: B 7 т. T. 5: Avtobiografitcheskaia proza. Stati.

Esse. Perevodi. Sost., podgot. teksta i komment. A.A. Saakiants i L. A. Mnukhina. Moscou: Ellis Lak, 1994b. 